\title{
Reply: "Auer Rod-Like Inclusions in Reactive Plasma Cells in a Case of Acute Myeloid Leukemia"
}

\author{
Cevap: "Akut Myeloid Lösemi Tanılı Bir Olguda Reaktif Plazma Hücrelerinde Auer Rod \\ Benzeri Inklüzyonlar"
}

\author{
Sarita Pradhan \\ Institute of Medical Sciences and Sum Hospital, Laboratory of Hematology, Bhubaneswar, India
}

To the Editor,

First I would like to thank Smeeta Gajendra for scrutinizing my article in her 'Comment: In Response to "Auer Rod-Like Inclusions in Reactive Plasma Cells in a Case of Acute Myeloid Leukemia"' published online and for bringing to light the missing reference of Sharma et al. [1], who reported a case of Auer rodlike inclusions in plasma cells in a case of therapy-related AML. I sincerely regret missing that article in my literature search but I would also like to clarify a few points.

My presented case was not secondary AML and the patient had no prior history of chemotherapy, unlike the case reported by Sharma et al. [1]. The aim of my publication was to highlight a rare and interesting morphological finding, but within a limit of
200 words it was not possible to acknowledge all hematological malignancies showing similar inclusions in plasma cells.

In conclusion, I would like to again thank Dr. Gajendra for the elaborate and informative additions made in the commentary.

Conflict of Interest: The author of this paper has no conflicts of interest, including specific financial interests, relationships, and/or affiliations relevant to the subject matter or materials included.

\section{Reference}

1. Sharma $S$, Malhan P, Pujani M, Pujani M. Auer rod-like inclusions in reactive plasmacytosis seen with acute myeloid leukemia. J Postgrad Med 2009;55:197.

\section{Auer Rods Are Not Seen in Non-Neoplastic Cells}

\section{Auer Cismi Neoplastik Olmayan Hücrelerde Görülmez}

İrfan Yavaşoğlu, Zahit Bolaman

Adnan Menderes University Faculty of Medicine, Division of Hematology, Aydın, Turkey

To the Editor,

The article entitled "Auer Rod in a Neutrophil in a Nonmalignant Condition", written by Chandra et al. [1] and published in a recent issue of your journal, was quite interesting. Here we would like to emphasize some relevant points.

This article demonstrates why peripheral smears, bone marrow examination, and genetic tests are mandatory. Acute myeloid leukemia must be excluded. Electron microscopic analyses would be helpful. The title is overly assertive. It may be called an Auer rod-like image.

It is not known why Auer rods are not seen in non-neoplastic cells. However, there have been some hypotheses on the genesis of Auer rods, including infectious microorganisms, abnormal nucleoplasm segregation, pathologic forms of azurophilic granules, and cytoplasmic $\mathrm{pH}$ alteration. Unsuccessful results in Auer body inoculation experiments led to the elimination of the infectious microorganism theory. Although the conditions 
for $\mathrm{pH}$ alteration are not known, Ackerman [2] suggested that cytoplasmic $\mathrm{pH}$ alteration occurred in specific leukemia cells, which allowed the granules to unite into crystal-like rods [3].

Additionally, a titration rate of $1 / 200$ or higher in 0 antigen should be considered positive for acute infection diagnosis. Salmonella Typhi isolation in culture is the gold standard for diagnosis [4].

Keywords: Auer rods, Non-neoplastic cells

Anahtar Sözcükler: Auer cismi, Neoplastik olmayan hücreler

Conflict of Interest: The authors of this paper have no conflicts of interest, including specific financial interests, relationships, and/or affiliations relevant to the subject matter or materials included.

\section{References}

1. Chandra H, Chandra S, Gupta V, Mahajan D. Auer rod in a neutrophil in a nonmalignant condition. Turk J Hematol 2016;33:167.

2. Ackerman GA. Microscopic and histochemical studies on the Auer bodies in leukemic cells. Blood 1950;5:847-863.

3. Yoshida $Y$, Oguma $\mathrm{S}$, Ohno H. John Auer and Auer rods; controversies revisited. Leuk Res 2009;33:614-616.

4. Mogasale V, Ramani E, Mogasale W, Park J. What proportion of Salmonella Typhi cases are detected by blood culture? A systematic literature review. Ann Clin Microbiol Antimicrob 2016;15:32.

\section{Reply}

Dear Sir,

The authors are thankful for considering their manuscript entitled "Auer Rod in a Neutrophil in a Nonmalignant Condition" interesting enough for critical analysis. However, the authors would like to clarify few points:

1. The authors have clearly stated in the manuscript the presence of Auer rod-like inclusions on peripheral examination.

2. In view of the presence of Auer rods bone marrow examination was done and which showed only unremarkable features of normoblastic maturation. There was presence of no leukemia cells. This clearly excluded the possibility of malignant condition and nonmalignant diagnosis was considered. Moreover the patient also responded well to an antibiotic course after diagnosis of typhoid.

3. Genetic studies were however not done as firstly it was not considered necessary in view of absolutely normal bone marrow and secondly also due to financial constraints.

4. The Salmonella Typhi 0 antigen titre of 1: 160 dilution was considered positive and patient responded very well to course of antibiotics. Her clinical follow up was unremarkable and thus chance of any leukemic process was completely eliminated.

5. The authors agree with the various hypotheses that have been enlisted by Yavaşoğlu and Bolaman for genesis of Auer rod in infectious conditions. In the background of these theories and findings, the presence of clear rod-like structure due to condensation of azurophilic granules in neutrophil in typhoid infection led to the consideration of Auer rod in nonmalignant condition.

Thanking you,

Harish Chandra, Smita Chandra, Vibha Gupta, Divyaa Mahajan 